\title{
Comparative Analysis of Raw Materials Control Using JIT and EOQ method For Cost Efficiency of Raw Material Supply in Automotive Components Company Bekasi, Indonesia
}

\author{
Jakfat Haekal $^{1}$ \& Ifnu Setiawan ${ }^{2}$ \\ ${ }^{1}$ Industrial Engineering Department, Faculty of Engineering, Universitas Mercu Buana \\ ${ }^{2}$ Quality Engineer, Automotive Component Company
}

\begin{abstract}
The company where the author conducted research is a company engaged in the automotive sector that produces various seals for motor vehicles and heavy equipment. The raw material used is rubber (synthetic rubber). This company has difficulty determining the amount of Rubber inventory by the needs so that there is no excess inventory stock that can cause excess inventory costs. The method used in this research is Economic Order Quantity (EOQ) and Just In Time (JIT). The author intends to compare the two methods to the cost efficiency of raw material inventory and choose which method is more appropriate for this company. From the research, it is known that the inventory costs incurred by the company are Rp. 6,048,000, while the result of the cost calculation using the EOQ method is Rp. 3,678,175 and Rp's JIT method. 1,320,945. It can be concluded that the JIT method has the smallest total cost of inventory compared to the EOQ method and the company method.
\end{abstract}

Key words: Economic Order Quantity (EOQ), Just In Time, Inventory Management, Efficiency.

\section{INTRODUCTION}

Currently, the automotive industry in Indonesia is developing very rapidly, making competition between automotive companies unavoidable. The competition will encourage each automotive company to provide better quality and service to continue to survive in the world of the automotive industry. The competition that occurs includes product quality, service quality, innovation, competitive prices, marketing strategies, and technology in production activities. Various factors within the company itself can influence the production process in a company; one of the most important is raw materials to support the smooth running of production activities.

According to Sofyan (2013), in Indiana's research (2017), one of the strategies that can help companies is to manage raw material supplies properly because the amount of inventory will affect the smoothness of the production process so that efficiency can occur for the company. All companies plan and control raw materials to minimize costs and maximize profits according to a specific time. The company's primary function is to have inventory so that the company can buy and make products in economic quantities. According to Baroto (2002), in Aprilia's (2018) research, poor raw material inventory management can cause errors such as miscalculating raw material needs, causing a lack of supply of raw materials for production activities that production activities stop. Inventory management is essential for the company because it requires about $20 \%$ to $60 \%$ of the company's investment. Determination of the amount of inventory is essential for the company because inventory directly impacts the company's production activities. Errors in determining the amount of inventory can suppress company profits. Raw material inventories that are too large compared to the company's needs will increase inventory costs, such as ordering costs and carrying costs, as well as the possibility of decreasing inventory quality, obsolescence, and damage, so that it can reduce company profits. Likewise, on the other hand, the supply of raw materials that is too small in the company will cause bottlenecks in the production process, so that the company will suffer losses as well.

For product quality, it is also closely related to suppliers of raw materials for production. Therefore companies must choose suppliers who provide quality raw materials and provide these raw materials exactly when needed because the length of time raw materials are on the way can affect the quality of these raw materials, causing the product to result in less quality. Besides 
suppliers, product quality is also closely related to the length of time raw material supplies are stored. Raw materials stored for too long can become obsolete, damaged, unusable, or unsuitable for production. This can cause losses for the company.

The company where the author conducted the research is a company engaged in the automotive sector that produces various kinds of seals for motor vehicles and heavy equipment, one of which is the O-Ring product. This company's raw material to make ORing products is rubber (synthetic rubber) in the form of thick sheets. Rubber has a service life of a week; after the rubber has passed its service life (expired), the rubber's texture will become more challenging and decrease its elasticity level, so it is not suitable for production activities because it can produce defective products. Rubber is delivered once a week by the supplier according to the schedule predetermined by this company. In its business activities, this company has difficulty determining the amount of rubber raw material inventory that is by the needs so that there is no excess inventory stock that can make raw materials expire before they are used up for production activities reduce inventory costs.

Table 1 Rubber Inventory Data for 2019

\begin{tabular}{|c|c|c|c|c|c|c|c|c|}
\hline Bulan & $\begin{array}{c}\text { Initial } \\
\text { inventory }\end{array}$ & Purchase & $\begin{array}{c}\text { Total } \\
\text { Inventory }\end{array}$ & Demand & $\begin{array}{c}\text { Ending } \\
\text { Inventory }\end{array}$ & $\begin{array}{c}\text { Safety } \\
\text { Stock }\end{array}$ & $\begin{array}{c}\text { The } \\
\text { rest }\end{array}$ & Remark \\
\hline January & 250 & 1.400 & 1.650 & 1.395 & 255 & 200 & 55 & Lebih \\
\hline February & 255 & 1.400 & 1.655 & 1.401 & 254 & 200 & 54 & Lebih \\
\hline March & 254 & 1.400 & 1.654 & 1.386 & 268 & 200 & 68 & Lebih \\
\hline April & 268 & 1.400 & 1.668 & 1.380 & 288 & 200 & 88 & Lebih \\
\hline May & 288 & 1.400 & 1.688 & 1.324 & 364 & 200 & 164 & Lebih \\
\hline June & 364 & 1.300 & 1.664 & 1.212 & 452 & 200 & 252 & Lebih \\
\hline July & 452 & 1.400 & 1.852 & 1.406 & 446 & 200 & 246 & Lebih \\
\hline August & 446 & 1.400 & 1.846 & 1.388 & 458 & 200 & 258 & Lebih \\
\hline September & 458 & 1.400 & 1.858 & 1.359 & 499 & 200 & 299 & Lebih \\
\hline October & 499 & 1.400 & 1.899 & 1.480 & 419 & 200 & 219 & Lebih \\
\hline November & 419 & 1.400 & 1.819 & 1.414 & 405 & 200 & 205 & Lebih \\
\hline December & 405 & 1.400 & 1.805 & 1.386 & 419 & 200 & 219 & Lebih \\
\hline Total & $\mathbf{4 . 3 5 8}$ & $\mathbf{1 6 . 7 0 0}$ & $\mathbf{2 1 . 0 5 8}$ & $\mathbf{1 6 . 5 3 1}$ & $\mathbf{4 . 5 2 7}$ & & $\mathbf{2 . 1 2 7}$ & $\mathbf{1 . 3 7 7 , 5 8}$ \\
\hline Average & $\mathbf{3 6 3 , 1 7}$ & $\mathbf{1 . 3 9 1 , 6 7}$ & $\mathbf{1 . 7 5 4 , 8 3}$ & $\mathbf{3 7 2 5}$ & & & \\
\hline
\end{tabular}

This company has remaining rubber raw materials that exceed the safety stock with $2,127 \mathrm{~kg}$, which will cause excess storage costs such as electricity costs and warehouse maintenance costs. According to Lestari et al. (2019) in his journal entitled "Comparison of Economic Order Quantity and Just In Time Methods Against Inventory Cost Efficiency," the impact of poor raw material management is the emergence of waste from material wasted due to damage or deterioration of quality and excess inventory costs. With the same methods and problems, the research becomes a reference for selecting methods in this study. Based on the problems faced by this company, the writer intends to compare the EOQ and JIT methods to determine which method is more appropriate to determine the optimal rubber order quantity and reduce inventory costs.

\section{LITERATURE SURVEY}

\subsection{EOQ}

According to Riyanto (2001) in Apriyani \& Muhsin's (2017) research, Economic Order Quantity (EOQ) is a technique for procuring raw material supplies in a company by determining the number of orders that are economical for each order with a predetermined order frequency and when it is done. Reorder.

The Economic Order Quantity (EOQ) method can be used for both purchased and self-produced goods. The EOQ method is commonly used for items purchased, while the Economic Lot Size (ELS) is used for goods that are self-produced. The main difference is that the ordering cost includes the cost to prepare the order and the setup cost needed to work on the order for ELS. The EOQ assumptions are:

1. The number of requests is known, constant, and independent 
2. The waiting time, i.e., the time between ordering and receiving the order, is known and constant

3. Inventory receipt is instant and wholly completed

4. There is no quantity discount available

5. Variable costs are just the costs of preparing or placing an order and the costs of keeping inventory for a specified time

6. Out of stock can be avoided entirely if the order is made on time

\subsection{JIT}

According to Poojary et al. (2015), in Triana's research (2019), companies' ability to compete at more competitive prices can be done by reducing operational costs or production costs by implementing Just in Time, known as JIT. JIT's view is to use Time to prevent waste in production activities. The sources of waste identified by Toyota and first introduced by Taiichi Ohno, known as Toyota's Seven Wastes, are:

1. Waste from producing defective products

2. Waste in transportation and material handling

3. Waste of inventory (inventory)

4.Overproduction

5. Waste of waiting Time

6. Waste in a process

7.Motion waste

There are two production systems known in JIT, namely the pull system and the push system.

1. Push system is a production system that directs products to consumers. The company does not pay attention to demand. The system's weakness is when the product continues to be produced without seeing the actual demand, and then there will be an accumulation of goods in the warehouse, which takes up factory space.

2. In a pull system, production activities will run based on actual demand. The company will only produce goods when there are orders from consumers.

According to Hansen et al. (2001) in a study by Simanjuntak et al. (2017), Just In Time is a manufacturing approach which states that products must be withdrawn from the entire system with demand, rather than pushing the entire system with a fixed schedule to anticipate demand. Just In Time is a comprehensive production system and inventory management system where raw materials are purchased and produced as needed and used at the Right Time in every production process.

According to Hay (1990) in the research of Khan et al. (2017), producing a small number of lots allows the Just In Time system to operate more effectively, so that many benefits can be obtained, such as less space required, less WIP (work in process) items, and increased flexibility in scheduling.

According to Supriono (2007) in a study by Simanjuntak et al. (2017), The Just In Time method can reduce Time and costs associated with purchasing activities by:

a. Reducing the number of suppliers,

b. Reducing or eliminating the Time and costs of negotiating with suppliers,

c. Have consumers with an established purchasing program,

d. Eliminate or reduce activities and values that are not added value,

e. Reducing Time and costs for quality inspection programs.

According to Supriyono (2007), in a study by Simanjuntak et al. (2017), JIT production can reduce production time and costs by:

a. Reduce or eliminate work in progress

b. Reduce or eliminate Lead Time

c. Reduce or cancel setup

d. Simplify product processing

\section{OBJECTIVE OF THE RESEARCH}

Based on the background of the problems discussed earlier, the objectives of this study are:

1. Comparing the EOQ and JIT methods to the efficiency of the cost of raw material inventories in this company.

2. Choose the method that has the lowest cost of inventory to be applied in this company.

\section{RESEARCH METHODOLOGY}

Research activities require exact methods. In this case, there are two research methods, namely, qualitative and quantitative methods. Quantitative research methods are research methods based on the philosophy of positivity used to examine a particular sample or population. The sampling technique is generally carried out randomly. Data collection uses quantitative/statistical data analysis research instruments to test the predetermined hypothesis. Qualitative research methods are referred to as naturalistic research methods because the research is carried out in natural conditions (natural setting), also known as methodetnographies, 
because at first this method was mostly used for research in the field of cultural anthropology called qualitative methods because the data collected and Analysis were more qualitative.

The type of this research is quantitative research because this research is a research in a company in the automotive sector regarding raw material inventory control using the Economic Order Quantity (EOQ) method and the Just In Time (JIT) method, where the data is in the form of raw material inventory data years which are more numerical than narrative.

The problems discussed in this study were determining the best method between the EOQ method and the JIT method to be applied in this company to control raw materials.

Methods of processing and data analysis carried out by the author are:

i. Inventory System Analysis

ii. At this stage, an analysis of the rubber raw material supply process is carried out in this company. In the research inventory system analysis defines:

a. How much is the demand for the product to be produced.

b. How to process the existing inventory in the company.

c. How much will it cost for supplies.

iii. Rubber raw material inventory planning

iv. At this stage, to apply the Economic Order Quantity (EOQ) and Just In Time (JIT) method, research requires several steps. The steps taken by the researcher are:

a. Knowing the amount of demand for products that use rubber raw materials

b. Knowing the lead time for ordering Rubber.

c. Knowing the costs regarding raw materials.

d. Calculating data using the EOQ \& JIT method.

e. Compare and find the minimum cost of EOQ and JIT methods.

\section{Analysis Using the Economic Order Quantity (EOQ) Method}

To determine the optimal amount of raw material purchases per order, it is necessary to calculate the optimal economic quantity or Economic Order Quantity (EOQ).

a. Calculating the amount of economical raw material purchases in the EOQ method

b. The optimal ordering frequency in the EOQ method

c. Total Inventory Cost

The total inventory cost is the sum of the total ordering costs, plus the total storage costs per year. Ordering costs are obtained from the number of raw material requirements multiplied by the cost each time you place an order, then divided by the optimal order amount of raw materials. The storage cost is obtained from the storage cost per unit per year multiplied by the optimal order quantity of raw materials and then divided by two. The calculation of the total cost of raw material inventories in the EOQ method

d. Determining Safety Stock (safety stock) in the EOQ method

e. Determining the Reorder Point in the EOQ method

\section{Data Analysis Using the Just In Time (JIT) Method}

Calculate the optimal order quantity and total cost of inventory using the Just In Time method:

a. Determining the optimal amount of raw material shipments JIT method

b. Determining the Optimal Ordering Quantity of Raw Materials The JIT method

c. Determining the optimal shipment quantity for each delivery of raw materials using the JIT method

d. Determining the Frequency of Ordering Raw Materials The JIT method

e. Calculating the total cost of raw material supplies

\section{RESULT AND DISCUSSION}

From the data processing carried out by the author, the following results were obtained:

\section{EOQ Method Data Processing Results}

The results of data processing performed by the author using the EOQ method are as follows:

1. Purchasing Economic Raw Materials $=835.95 \mathrm{~kg}$

2. From the above calculation, it is known that the quantity of economical raw material purchases is $835.95 /$ message

3. Optimal Ordering Frequency $=19.78$ times 
4. The optimal ordering frequency to meet raw material needs in a year is 19.78 times

5. Total Cost of Inventory $=$ Rp. 3,678,175

6. The total cost of supplies for a year is Rp. 3,678,175

7. Safety Stock (Stock Safety) $=114.31 \mathrm{~kg}$

8. To maintain smooth production, a safety stock or safety stock of $114.31 \mathrm{~kg}$ is required

9. Reorder Point (Point Message Back) $=458.70 \mathrm{~kg}$

When the raw material inventory level reaches $458.70 \mathrm{~kg}$, the company must place an order for raw materials.

\section{Results of Data Processing Just In Time Method}

The results of data processing by the author using the Just In Time method are as follows:

1. Optimal amount of delivery of raw materials $=7.75$ times

The optimal number of shipments of raw materials in one order is 7.75 times.

2. Optimal Ordering Quantity of Raw Materials $=2,327.70 \mathrm{~kg}$

The optimal order quantity of raw materials in one order is $2,327.70 \mathrm{~kg}$.

3. Optimal Shipping Quantity $=300.21 \mathrm{~kg}$

The optimal delivery quantity is $300.21 \mathrm{~kg}$, with a frequency of 7.75 times per message.

4. Frequency of Ordering for Raw Materials $=7.1$ times

The frequency of ordering raw materials in a year is 7.1 times

5. Total Cost of Raw Material Inventory = Rp. 1,320,945

The total cost of raw material inventory in a year is Rp. 1,320,945.

\section{Comparison of Data Processing Results}

Comparing the results of data processing between the EOQ method and Just In Time with the company method is presented in the table below.

Table 2. Comparison of Data Processing Results

\begin{tabular}{|l|c|c|c|}
\hline & Company Method & EOQ Method & JIT Method \\
\hline $\begin{array}{l}\text { Raw Material } \\
\text { Requirements / year }\end{array}$ & $16.531 \mathrm{~kg}$ & $16.531 \mathrm{~kg}$ & $16.531 \mathrm{~kg}$ \\
\hline $\begin{array}{l}\text { Optimal Order } \\
\text { Quantity }\end{array}$ & $1.377,58 \mathrm{~kg}$ & $835,96 \mathrm{~kg}$ & $2.327,70 \mathrm{~kg}$ \\
\hline $\begin{array}{l}\text { Order Frequency / } \\
\text { year }\end{array}$ & $48 \mathrm{kali}$ & $19,78 \mathrm{kali}$ & $7,1 \mathrm{kali}$ \\
\hline $\begin{array}{l}\text { Delivery / message } \\
\text { frequency }\end{array}$ & $1 \mathrm{kali}$ & $1 \mathrm{kali}$ & $7,75 \mathrm{kali}$ \\
\hline Total Inventory Cost & Rp. 6.048 .000 & Rp. 3.678.175 & Rp. 1.320 .945 \\
\hline
\end{tabular}

From the table above, it can be seen that the company's optimal order quantity based on the average raw material requirement is $1.377 .58 \mathrm{~kg}$, while the EOQ method is $835.96 \mathrm{~kg}$ and the JIT method is $2.327 .70 \mathrm{~kg}$. The frequency of ordering raw materials using the company method is 48 times or per week for a year, whereas the EOQ method is 19.78 times, and for JIT, it is 7.1 times. Especially for the JIT method, raw materials' delivery is carried out as much as 7.75 times in one message. The total inventory cost using the company method is Rp. 6,048,000, while the EOQ method is Rp. 3,678,175 and the JIT method of Rp. $1,320,945.49$. 


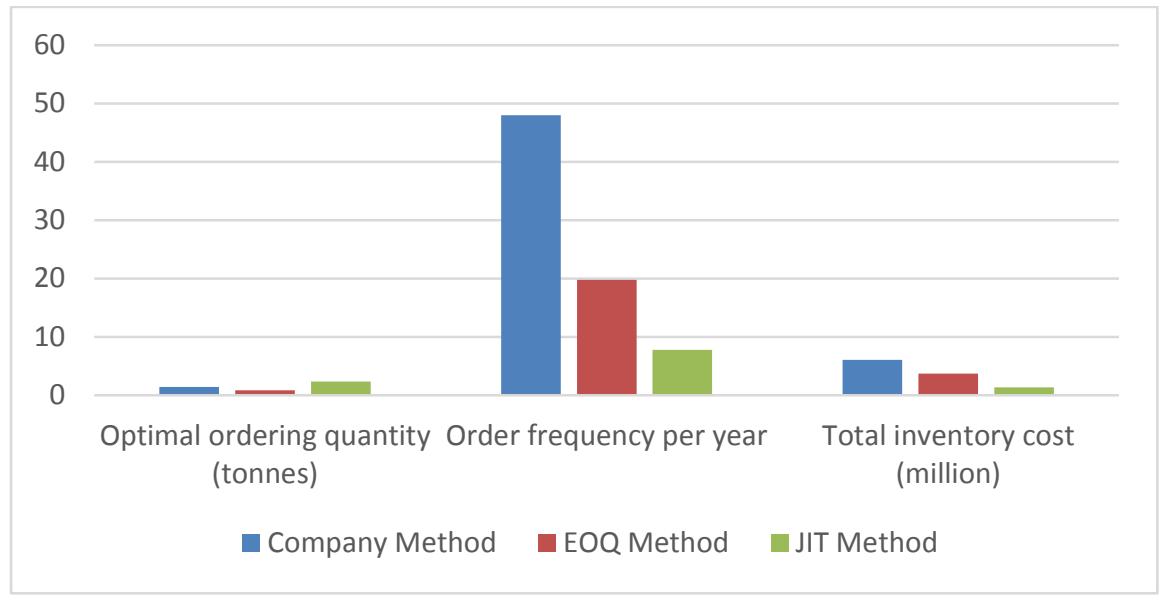

Figure 1 Comparison Chart of EOQ and JIT Methods

From the graph above, it can be seen that the EOQ method has a smaller optimal ordering quantity (835.96 kg), a more significant order frequency (19.75 times), and a more massive total inventory cost (Rp.3,678,175) than the JIT method. . Meanwhile, the JIT method has a larger quantity $(2,327 \mathrm{~kg})$, a smaller order frequency (7.1 times) and a smaller total cost of inventory (Rp. $1,320,945)$ compared to the EOQ method.

\section{CONCLUSION}

Based on the research conducted by the author, the following conclusions can be drawn:

1. The optimal ordering quantity using the company method is $1.377 .58 \mathrm{~kg}$; the smallest optimal ordering quantity is obtained from the EOQ method, which is $835.96 \mathrm{~kg}$ while using the Just In Time method is $2.327 .70 \mathrm{~kg}$. The frequency of ordering raw materials using the company method was 48 times while using the EOQ method was 19.78 times, and the Just In Time method was 7.1 times ordering with a frequency of 7.75 times sending in one message. The total inventory cost using the company method is Rp. 6,048.00; the EOQ method is Rp. 3,678,175, and the Just In Time method of Rp. 1,320,945. Using the EOQ method, the total cost of inventory decreased by Rp. 2,369,825, while using the Just In Time method of Rp. 4,727,055.

2. Based on the calculation of the total inventory cost, it can be concluded that the Just In Time method is more suitable to be applied in this company because it has the smallest total inventory cost of Rp. 1,320,945.49. The Just In Time method can reduce inventory costs because companies only order raw materials when needed, so there is no excess stock while reducing the cost of storing raw materials.

\section{SUGGESTION}

The following are suggestions related to the research conducted by the author:

1. To maintain the smooth running of production activities, companies are advised to have more than one supplier because the Just In Time method requires timeliness and quantity of raw material shipments. If you only depend on one supplier, production activities can experience disruption when the supplier is late or cannot deliver raw materials according to the requested time and quantity.

2. Include the lifetime of rubber as a consideration for making production plans and purchasing raw materials so that there is no decline in the raw materials' quality before the raw materials are used up.

\section{ACKNOWLEDGMENT}

Universitas Mercu Buana Research Centre funded this research. We are grateful for all experts who are willing to be research partners, with no mention of the company name. 


\section{REFERENCES}

1. Haekal, J., Hanum, B., \& Adi Prasetio, D. E. 2020. Analysis of Operator Body Posture Packaging Using Rapid Entire Body Assessment (REBA) Method: A Case Study of Pharmaceutical Company in Bogor, Indonesia. International Journal of Engineering Research and Advanced Technology - IJERAT (ISSN: 2454-6135), 6(7), 27-36.

2. Hanum, B., Haekal, J., \& Adi Prasetio, D. E. . 2020. The Analysis of Implementation of Enterprise Resource Planning in the Warehouse Division of Trading and Service Companies, Indonesia . International Journal of Engineering Research and Advanced Technology - IJERAT (ISSN: 2454-6135), 6(7), 37-50.

3. Kholil, M., Haekal, J., Eko Adi Prasetio, D. ., \& Sulaiman Hasan. 2020. The Lean Manufacturing Design For Improving Production Scheduling Using Product Wheel Method in Chemical Manufacturing Company, Indonesia. International Journal of Engineering Research and Advanced Technology - IJERAT (ISSN: 2454-6135), 6(8), 12-18.

4. Haekal, J., \& Setio, H. 2017. Selection of Raw Material Suppliers Using Analytical Hierarchy Process in Food and Beverage Company, South Jakarta. ComTech: Computer, Mathematics and Engineering Applications, 8(2), 63-68.

5. HAEKAL, J. (2018). PERANCANGAN DAN EVALUASI IMPLEMENTASI SISTEM MANAJEMEN MUTU ISO 9001: 2015 MELALUI KEPUASAN PELANGGAN DI UNIVERSITAS ISLAM AS-SYAFI'IYAH (Doctoral dissertation, Universitas Mercu Buana Jakarta).

6. Kholil, M., Haekal, J. H, Sulaiman. 2020. Lean Manufacturing Design to Reduce Waste in Gear Production Process Using VSM and Kaizen Method Approaches (Case Study: Gear Primary Driven K56 Product). Journal of Scientific and Engineering Research. 7(8), 1-9

7. Haekal, J., Hanum, B., \& Adi Prasetio, D. E. 2020. Application of Quantitative Strategic Planning Matrix (QSPM) For Determination of Alternative Strategies in Food and Beverage SMES in Bogor Indonesia. Journal of Scientific and Engineering Research. 7(7), 137-145

8. Hanum, B., Haekal, J., \& Adi Prasetio, D. E. . 2020. SPHC Material Inventory Control Analysis in Project VL01 Centralized by the EOQ Method in Automotive Company Indonesia. Journal of Scientific and Engineering Research. 7(7), 130-136

9. Andiana, M. (2017). Aplikasi Metode EOQ Dalam Pengendalian Persediaan Bahan Baku PT X. Jurnal Akuntansi Maranatha, Vol. 10(1), Hal. 31.

10. Aprilia, A., Sidik, M., D. \& Fujiyanti, L. 2018. Sistem Penunjang Keputusan Persediaan Produksi Grafika Dengan Pendekatan Economic Order Quantity (EOQ). Jurnal Pasti, [online] Vol. 7(1), Hal. 34-49.

11. Apriyani, N. \& Muhsin, A. 2017. Analisis Pengendalian Persediaan Bahan Baku Dengan Metode Economic Order Quantity Dan Kanban Pada PT. $\quad$ Adyawinsa Stamping Industries. Jurnal Optimasi Sistem Industri,

12. Bhargava, A. 2017. A Study on The Challenges And Solutions To Just In Time Manufacturing. International Journal of Business and Management Invention, [online] Vol. 6(12), Hal 47-54.

13. Chuong, S. C. \& Stevenson W. J. 2014. Manajemen Operasi: Prespektif ASIA (9 ${ }^{\text {th }}$ ed.). Jakarta: Salemba Empat.

14. Elmas, M. S. H. 2017. Analysis Control Supplies Raw Material With The EOQ Methods In The Smoothness Of The Production Process. International Journal of Social Science and Business, [online] Vol. 1(3), Hal. 186-196.

15. Fajrin, E. H. A. \& Slamet, A. 2016. Analisis Pengendalian Bahan Baku Dengan Menggunakan Metode Economic Order Quantitiy (EOQ) Pada Perusahaan Roti Bonansa. Management Analysis Journal Universitas Negeri Semarang, [online] Vol. 5(4), Hal. 292.

16. Herjanto, E. 2009. Sains Manajemen - Analisis Kuantitatif Untuk Pengambilan Keputusan. Jakarta: Grasindo.

17. Nasution, A. H., \& Prasetyawan, Y. 2008. Perencanaan \& Pengendalian Produksi (1 ${ }^{\text {st }}$ ed.). Yogyakarta: Graha Ilmu. 18. Prawirosentono. 2005, Riset Operasi Dan Ekonofisika ( $1^{\text {st }}$ ed.). Jakarta: Bumi $\quad$ Aksara.

EMAIL: Jakfat.haekal@ mercubuana.ac.id 